THE DEVELOPMENT OF THE INTERFACE BETWEEN LAW, MEDICINE AND PSYCHIATRY: MEDICO-LEGAL PERSPECTIVES IN HISTORY

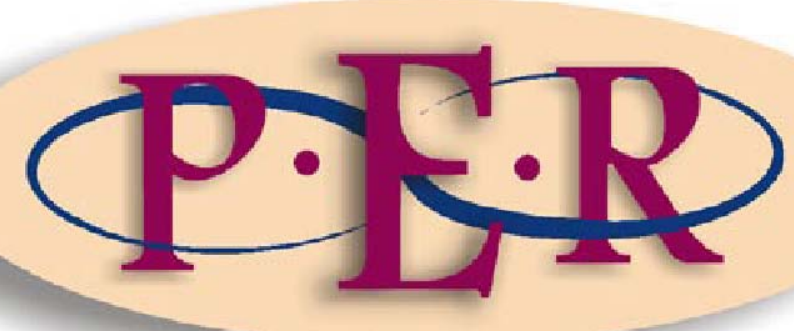

2009 VOLUME 12 No 4 


\section{THE DEVELOPMENT OF THE INTERFACE BETWEEN LAW, MEDICINE AND PSYCHIATRY: MEDICO-LEGAL PERSPECTIVES IN HISTORY}

M Swanepoel*

History, despite its wrenching pain, cannot be unlived, but if faced with courage, need not be lived again. ${ }^{1}$

\section{Introduction}

\subsection{Background}

Medicine and law were related from early times. This relation resulted as a necessity of protecting communities from the irresponsible acts of impostors. ${ }^{2}$ Various legal codes dealing with medical malpractice existed in Egypt, Mesopotamia, China, Islam, Greece, Rome, Persia and India. The first documented Code of Laws ever used by human civilisation in, for example, Mesopotamia is to be found from the Law Code of Hammurabi ${ }^{3}-$ a textual source of evidence concerning the skills of Mesopotamian physicians. It was also Hammurabi who made the first declaration of human rights in history:

* Magdaleen Swanepoel. LLB LLM (Pret) LLD (Unisa). Senior Lecturer, Department of Jurisprudence, Unisa. This article is an abstract from and an adaptation of Swanepoel Law, Psychiatry and Psychology. Special recognition is given to my promoter Prof Melodie Slabbert (Unisa) and Dr Louise Olivier (Clinical and Counselling Psychologist) for being great teachers and for their advice, inspiration and support, not only in the writing of this article, but also in the writing of the thesis.

1 Angelou 'Inaugural Poem' as quoted in Stout Psychology of Terrorism 39.

2 Guharaj Forensic Medicine 1.

3 Hammurabi's activity as king of Babylonia dates from the middle of the $23^{\text {rd }}$ century. From a legal point of view, there is much fundamental value to be found in the Code of Hammurabi. According to Price, the legal fraternity will find that Roman law has its roots in Babylonia, Egypt, and Persia, and that the ancient world was so admirably organised as to furnish better protection, in some respects, to its subjects than does our boasted civilisation of this day. The epilogue too is a remarkable document, which describes the benefits accruing to the subjects of Hammurabi from observance of these righteous laws, and calls down the wrath of the gods upon the transgressor. Like the Roman lus civile, the Hammurabi Code is divided into three sections: Ius actionum, lus rerum and lus personarum (this is usually found in reversed order in Roman law). See Price 1904 Bib'l World 469, 472; Pfeiffer $1920 \mathrm{Am} \mathrm{J} \mathrm{Sem} \mathrm{L \& L} \mathrm{313.} \mathrm{For} \mathrm{further} \mathrm{reading} \mathrm{on} \mathrm{Hammurabi's}$ Code of Law see Duncan 1904 Bib'l World 188-193; Vincent 1904 Am J Sociology 737754; Lyon 1906 J Am Oriental Society 123-134; Prince 1910 J Bib'l Lit 21-23. 
Anu [king of the Anunaki] and Bel [Lord of heaven and earth] called me, Hammurabi ... to cause justice to prevail in the land, to destroy the wicked and evil, to prevent the strong from oppressing the weak, to go forth like the sun over the blackheaded race, to enlighten the land and to further the welfare of the people. Who made justice to prevail, and who ruled the race with right. I established law and justice in the land, and promoted the welfare of the people. ${ }^{4}$

Although individual physicians had occupied themselves with the care of the insane and had written manuals about it since the time of the ancient Greeks, psychiatry $^{5}$ did not then exist as a discipline to which a group of physicians devoted themselves with a common sense of identity. Yet, except for surgery, few other specialities had come to life either. The advent of medical specialism ${ }^{6}$ was a phenomenon of the nineteenth century, but mental disorders ${ }^{7}$ as such had always been familiar and society has always had ways of coping with it. ${ }^{8}$

4 Prologue in the Code of Hammurabi 1795-1750 BC as quoted in Price $1932 \mathrm{~J}$ Am Oriental Soc 177.

5 Psychiatry developed as a clinical and academic profession (a medical speciality) in the early nineteenth century. It is then when it became a subject of clinical demonstration and a discipline in its own right. The term "psychiatry" was first coined in 1808 by Johann Christian Reil (1759-1813), from the Greek words psyche (soul) and iatros (doctor). The word psychiatry also refers to 'healer of the spirit'. See Richards 1998 Critical Inquiry 702ff; Broman 1989 Osiris 36.

6 The origin and development of medicine and medical specialism can be divided into three periods: The Mythological period from infancy of the human race to about the year 400 $\mathrm{BC}$; the Dogmatic period or Empirical age from the Hippocratic period from $400 \mathrm{BC}$ to the close of the eighteenth century and the Rational age in medicine beginning at the close of the eighteenth century and the beginning of the nineteenth century. See Massengill Sketch 10; Carstens and Pearmain Foundational principles 608.

7 When mentioning mental disorders, a complicating factor is the absence of agreement on the most appropriate terminology. Currently mental illness, mental disorder, mental incapacity, psychiatric disability, psychiatric illness, mental disability, psychosocial disability, intellectual disability and several other terms are all used with different connotations and shades of meaning. Some of the terms reflect very important and sensitive debates, such as the discussion about a 'medical model' or 'social model' of functioning. Moreover, terminology has also evolved significantly in recent years and continues to do so. Eg, intellectual disability, once commonly referred to as mental retardation or handicap, is now sometimes referred to as developmental disability. Manic depression is now referred to as bipolar mood disorder. In this article the term mental disorder is most frequently used, although it is sometimes used interchangeably with some of the terms mentioned above. These terms currently include disorders arising from major mental illness and psychiatric disorders, eg, schizophrenia and bipolar disorder and more minor mental ill health and disorders, often called psychosocial problems, eg, mild anxiety disorders and intellectual disabilities. The term disorder is used to refer to a range of impairments, activity limitations, and participation restrictions, whether permanent or transitory. See Hunt and Mesquita 2006 HRQ 335.

Shorter History of psychiatry 1. 
The origin of psychiatry actually begins with the Greeks. The Greco-Roman outlook survived unchanged until the eighteenth century and even a large part of the Greek nomenclature is still used today. While the great cultures of old, such as those of Egypt and Mesopotamia vacillated between naturalistic and supernatural explanations of diseases, the Greeks declared themselves outspokenly in favour of naturalistic explanations of mental disorders and therefore became the founders of scientific medicine and psychiatry. ${ }^{9}$ The development of the interface between law and psychiatry results in a vast area of consideration and the scope of the research (which could not aim to be complete in an article of limited scope) is therefore immense. This article discusses and focuses on the development of these fields including pre-historic times, the Nile Valley as well as the Greek and Roman Period by following (where possible) a chronological approach. Further developments with regard to the position in South Africa are discussed in a separate article. It is important to note that terminology in this article is employed as it was used by medical historians, philosophers, medical practitioners and academic writers of the specific period in time to ensure that the desire for historical accuracy is reflected.

\subsection{The interface between law, medicine and psychiatry}

Medicine and law have been related from ancient times. The bonds that first united these professions were religion, superstition and magic. ${ }^{10}$ The priest, the jurist and the physician were at once united in one person. ${ }^{11}$ Physicians and legal practitioners in advanced societies are usually struck by the following synthesis:

Medicine is the law, and the law is medicine, and the amalgam is perfused and strengthened by the authority of tradition, religion, and the arts, such as music, the dance, and painting. ${ }^{12}$

9 Ackerknecht Psychiatry 10.

10 Wecht $2005 \mathrm{~J} \mathrm{Am}$ Acad Psychiatry L 245.

11 Smith 1936 JCL\&C 505.

12 The Native Doctor's Philosophy as quoted in Cawte Medicine xxii. 
They are surprised to find that their respective professions arise from a common source in prehistoric societies, because today these streams are so sharply differentiated that physicians, psychiatrists, psychologists and legal practitioners scarcely move in the same circles or talk the same language. In early civilisations, primitive legal codes, religious doctrines and social precepts were often ill distinguished, and laws with a medical content were often found within their context. ${ }^{13}$ In primitive societies medicine was concerned with magical power over natural objects, exercised through rites, spells and charms. In modern medicine physicians believe they are emancipated from these rites, spells and charms. Cawte ${ }^{14}$ however argues that they admit some responsibility - through the branch of psychiatry (and psychology) - for the control of emotional and behavioural disturbances. Some may find it tantalising that primitive men achieved a synthesis of medicine and justice that escapes the technocrats of today where others may accept this dissociation as the price of specialisation and progress. ${ }^{15}$

The 'law of madness' provided a way in which societies conceived madness, was (and still is) contiguous to that of medical and legal professions. At the centre of traditional medical discourse were the concepts of disease and diagnosis. This is as true of the history of psychiatry as of any other branch of medicine. The medical causes of mental disorders have long been a matter of medical debate, and the relationship between patient and doctor has been characterised as one of cure or, at least, care. Pivotal to the legal discourse, instead, were the protection of society and whether individuals were responsible for themselves and their actions. In this relatively broad understanding of the history of 'madness', the relevance of legal sources is

13 Wecht (n 10) 245.

14 Cawte (n 12) xvii, xviii, xxi.

15 The formation of Medico-Legal Societies testifies to the need felt by members of these professions to ingrate more closely. The purpose of these societies is to promote medicolegal knowledge in all aspects. In 1867, a Medico-Legal Society was organised in New York. It was the first society in the world to be organised for the purpose of promoting the principles that an attorney could not be fully equipped for the prosecution or the defense of an individual indicted for homicide without some knowledge of anatomy and pathology and that no physician or surgeon could be a satisfactory expert witness without some knowledge of the law. Harvard University established a separate professorship in legal medicine in 1877. See Cawte (n 12) xxii; Wecht (n 10) 248. 
clear. At the most fundamental level, law determines the rights of the mentally disordered patient and the legal liability of the health care practitioner. Therefore since ancient times medicine and law were conceived as spanning a large part of a person's relationships: with the care (medicine) and control (law) of their members. ${ }^{16}$ It becomes evident from the discussion in this article that often legal and medical approaches interact in co-operative ways in such a manner that it raises the question of whether they should be considered two histories or one.

\section{The development of medicine, madness and physician liability}

\subsection{Paleopathology ${ }^{17}$}

Medical science has its origin and its foundation in the science of paleopathology. The study of the ancient evidences of disease is a phase of medical history which must depend upon paleontological data for its extension. The fact that pathological lesions, especially those on the bones, retain all of their characteristics after many hundreds of thousands and millions of years has been clearly shown and distinct evidences of disease are known as far back in geological time as the Carboniferous. ${ }^{18}$ According to Moodie ${ }^{19}$ the relation of paleontological data to medical history is based on the assumption that the manifestations of disease are the same whether seen on man or in animals. The importance of paleopathology is that it gives an opportunity of studying evidences of disease over a great period of time, and especially is this true in regard to the data offered by paleontology.

16 Bartlett 2001 Soc Hist Med 108.

17 The term 'paleopathology' was proposed by Mark Armund Ruffer (1859-1917) in 1914 during his studies on the pathology of ancient Egyptian mummies. He defined paleopathology as the science of the diseases that can be demonstrated in human and animal remains of ancient times. The Paleolithic era (Old Stone Age), coincides with the geological epoch known as the Pleistocene (Great Ice Age) which ended about 10000 years ago with the last retreat of the glaciers. See Magner History of medicine 1.

18 The Carboniferous Period (360-290 million years ago) is divided into two parts. The Lower Carboniferous, also called the Mississippian, began ca 360 million years ago and ended 310 million years ago. The Upper Carboniferous, or Pennsylvanian, extended from about 310 to 290 million years ago with the beginning of the Permian Period. See Harland Geological timescale vi, viii, xiv, 19, 40-48ff. Moodie 1918 Science 619. 
Paleopathology is thus the study of prehistoric disease and, as such, deals predominantly with skeletal remains and prehistoric populations. In its broadest sense, paleopathology deals with diseases in animal as well as human tissues, and consequently it is a field of interest to many scientific disciplines. When infection, malfunction, or traumas affect bones and teeth, the lesions or other abnormalities can be observed and studied, and in many cases the cause can be identified. The psychiatric profession finds great interest in the mutilations, scarifications, and decorations of prehistoric peoples and in burial customs and other cultural practices that have left their marks upon the skeleton or are depicted in stone or paint. ${ }^{20}$ This form of primitive surgery is discussed below.

\subsection{Prehistoric medicine and beliefs ${ }^{21}$}

The concept of medicine, and in particular mental disorders, during the Stone Age was a very mythical one. Mental disorders were assumed to stem from magical beings that interfered with the mind. It was universally believed that mental disorders were caused by supernatural phenomena. It represented a breakdown of the magical-religious system and was mainly attributed to a violation or neglect of ritual obligations and further by demonic possessions. Treatments for mental disorders were mostly provided by individual groups of shamans. ${ }^{22}$ Although not specialised in the sense that they earned their livelihood from their vocation, their role in society was nevertheless to represent

20 Kerley and Bass 1967 Science 642.

21 'Prehistory' is a term often used to describe the period before the existence of actual and original 'recorded history'. Because, by definition, there are no 'recorded history' from these times, the information known about this time period is informed by the fields of palaeontology, biology, palynology geology, archaeoastronomy, anthropology, archaeology and other natural and social sciences. Even though the date marking the end of prehistory (which is the date when written historical records became a useful academic resource) varies from region to region it is generally accepted that prehistory ended around 3500 BC in Egypt. See Kerley and Bass (n 20) 638ff. For further reading of prehistoric times see Wells Outline of history xiii, 50ff; Robinson Hellas 7, 13ff; Quennell and Quennell Everyday life 1ff. Stearns and Langer Encyclopedia 1-20.

22 Shamans have been credited with the ability to control the weather, divination, the interpretation of dreams, astral projection, and travelling to upper and lower worlds. Shamanism refers to a range of traditional beliefs and practices concerned with communication with the spirit world. There are many variations in shamanism throughout the world, though there are some beliefs that are shared by all forms of shamanism. For an in depth discussion of Shamanism see Campbell Masks of God 211-272; 311ff; Demetrio 1978 Asian Folklore Studies 57ff; Winkelman 1990 Ethos $308 \mathrm{ff}$. 
medical and legal belief and authority. These treatments often took the form of exorcisms in which the shaman would attempt to coax the evil spirit causing the illness. $^{23}$

Psychosurgery $^{24}$ might be one of the oldest of all medical procedures performed by primitive societies. ${ }^{25}$ This observation is supported by physical evidence dating back to Neolithic times. ${ }^{26}$ Some anthropologists speculate that Stone Age societies performed trepanning ${ }^{27}$ on people with mental disorders to release the evil spirits or demons from their heads. Ackerknecht states that the trepanation procedure is of the highest importance (in certain contexts) as it is the "sole existing tangible evidence" of prehistoric medicine and surgery. ${ }^{28}$ Archaeologists have found numerous human skulls showing signs of trepanation. ${ }^{29}$ According to Oakley and Winfred trepanation was frequently

23 For a full discussion of the topic see Brand $1970 \mathrm{~J}$ Contemp Psycotherapy 13ff; Mora "History of Psychiatry" 2034-2054.

24 Psychosurgery is defined as surgical operations performed on physical normal brain tissue to treat mental disorders rather than brain pathologies. Brain tissue is destroyed during the performance of the procedure. See Colman Dictionary of psychology 621; cf the term neurosurgery, which is defined as a branch of surgery devoted to treating disorders of the brain, spinal cord, and other parts of the nervous system. See Colman Dictionary of psychology 503.

25 According to Ackerknecht 'primitive surgery' is one of those arbitrary procedures, which are to a certain extent unavoidable if we try to analyse primitive phenomena for a better understanding of our own cultural processes, and which are justifiable as long as we remain aware of its arbitrary character. See Ackerknecht (n 9) 25.

$265500-2500 \mathrm{BC}$. This very short Neolithic time period represents the last part of the Stone Age. The era follows the terminal Holocene Epipalaeolithic periods, beginning with the rise of farming, which produced the 'Neolithic Revolution' and ending when metal tools became widespread in the Copper Age (Chalcolithic) or Bronze Age or developing directly into the Iron Age, depending on geographical region. For a discussion of this period see Weinberg 1951 Am J of Arch 121ff; Perrin 2003 Antiquity 732ff.

27 Trepanning (also spelt trephining) is known as a surgical procedure of cutting a hole in the skull in order to access the brain. A key feature of the wounds found in ancient skulls is the smoothness and shininess around the edges of the holes. This is a clear sign of new bone growth and evidence that the person whose skull was opened not only survived the operation but lived months or even years afterwards while the bone regrew and the skull structure healed. See Oakley et al 1959 Man 93; Feldman and Goodrich 2001 Neurosurgery 647, 648, 649ff.

28 Trepanation is also spelt 'trephination'. See Ackerknecht (n 9) 33-34.

29 The crudest method of performing this procedure was to simply scrape a hole in the skullcap with a polished mussel-shell. A second method was to make a circular cut in the bone with a flint or obsidian knife and to deepen it until the hard brain-membrane was reached. Third, the operation was performed by using a rusty nail, stone, or a hammer to remove the bone from the skull and finally, a wreath of tiny holes was made with a drill-bore, called 'trypanon' in Greek. These could be united easily with a chisel or knife. Such an operation took little time even with primitive tools. The term 'trepanning' originated from the latter procedure. See Oakley et al (n 27) 93-96. 
practiced by the 'battle-axe people' who constructed chambered tombs in the Seine-Oise-Marne area of France. ${ }^{30}$ So many skulls in their tombs have been trepanned that it seems probable that the operation had some ritual significance. Roundels of human skull bone have been found in early prehistoric graves suggesting that such objects were treated as fetishes by the shamans and prehistoric men. ${ }^{31}$

It is evident from the above that evil spirits and demons were identified to be the cause of mental disorders during prehistoric times. This ancient time period is the only known period in history which lacks evidence to suggest a materialistic cause ${ }^{32}$ of mental disorders which coexisted with a mentalistic explanation $^{33}$ in all the other eras. It is suggested that lack of scientific thoughts

$30 \quad 3100-2000$ BC. The Seine-Oise-Marne culture is the last culture of the Neolithic and first culture of the Chalcolithic in Northern France. The 'battle axe people' represent late Neolithic times (early Mesolithic). The name comes from the perforated cast copper battleaxes of a particular double-bladed form that were found at archaeological sites associated with them. Their successors, the Beaker culture, if they were in fact separate people, copied the new axe head types in stone, but everywhere the arrival of the 'battle-axe' or 'corded-ware' cultures mark the phasing out of the Neolithic time period. Trepanation was also occasionally practiced by early Danubians (3000 BC). For a discussion of this culture see Tilley Ethnography of the Neolithic 9-69, 325-335.

31 Another singular circumstance with reference to prehistoric trepanning is that some of the sculls have been left entire, while others have been largely mutilated to provide cranial amulets. Researchers have even wondered whether the demand for skull-bone contributed to the prescription of trepanations. There are actual records of amulets measuring about 8-9 $\mathrm{cm}$. It is argued that no medical reason can exist for making such enormous holes, and it is very unlikely that the patients survived the serious risk of infection with meningitis. See Oakley et al (n 27) 93-96.

32 A materialist monism cause of mental illness refers to the conception that mental events are nothing but neural events. This is a monist viewpoint because it implies the existence of only one dimension namely the neural dimension. See Refinetti 1992 www.circadian.org/.

33 Mentalism refers to the conception that mental events can be fully explained by psychodynamic concepts without any reference to the nervous system. This is a dualistic viewpoint, as it implies that mind and brain are distinct and independent from each other. Refinetti identifies five groups in which to classify the contenders in the mind-brain controversy, namely mentalism, materialist monism, organicism, psychophysical parallelism, and psychophysical complementarism and explains it as follows: Organicism goes one step past materialist monism, in the sense that it claims not only that mental events are neural events but also that each part of the brain is responsible for a particular class of mental events. Psychophysical parallelism refers to the conception that mind and brain are distinct but related to each other. This form of dualism may imply that mind and brain are only different sides of the same coin or even that neural activity induces mental activity. Finally, psychophysical complementarism refers to the conception that mental and neural events complement each other as causes of behaviour. According to Refinetti cognisance should be taken of the fact that these five conceptions could all be described as particular ways of dealing with the much broader materialism-idealism controversy. Indeed, materialist monism and organicism are clearly materialistic, mentalism is idealistic, 
made them believe in non-scientific cause of mental disorders. It was impossible for these prehistoric cultures to blame the cause of mental disorders on something non-scientific, because they did not have developed scientific techniques to diagnose materialistic causes for mental disorders. ${ }^{34}$ DeWitt explains it as follows:

[During] [t]he Stone Age man was no less intelligent than his posterity and whether by the spoken word or the dexterous hand he was capable of producing art, but the logic of his thought was confined within the limits marked by myth and magic, oracle and miracle. $^{35}$

The difficulties in making any formulation of the development of medicine, psychiatry and law of prehistoric civilisations are very great. Data on early periods are incomplete, not only because research has been limited but also because it has been directed toward special and restricted problems. It seems, however as if rules in prehistoric human societies were created through discussion. There was no 'written law' or 'holy book' from which to take guidance in for instance the regulation of the practice of shamans. It was the community that had authority - everyone and no one. No one presumed to be above others in authority. No one exhorted the group about laws laid down by any of the spirits whose presence they felt. These difficulties mean primarily that any present formulation on legal and medical developments during this time period is highly tentative. ${ }^{36}$

and the other two conceptions are paradoxically both idealist and materialist. See Refinetti 1992 www.circadian.org/.

34 Swinton Spirituality 40-92.

35 DeWitt 1947 Classical J 195.

36 Steward 1949 Am Anthropologist 16. 


\subsection{Western medicine ${ }^{37}$}

\subsubsection{The Nile Valley}

The main sources for studying medical knowledge in ancient Egypt during the Pharaonic era ${ }^{38}$ are the surviving papyri, ${ }^{39}$ which first required transliteration into modern languages. Ancient Egyptians thought that diseases were either due to evil spirits or the wrath of the gods. Organic causes for illnesses were also described. ${ }^{40}$ Their philosophy of life and death centred upon the idea that these were part of a continuous cycle - the belief that life after death demanded elaborate funeral ceremonies and complex rituals in preparation for it. This

37 Western medicine, with its objective, pragmatic, fact-orientated philosophies and methodologies, and traditional Eastern medicine, with its intuitive holistic philosophies, are the products of two great civilisations in the medical history of mankind and they contribute to the health of a huge proportion of the world population. Studying the medical history of both these traditions provides the possibility of looking at things from two different points of view - as part of a whole - not understandable without understanding the whole or as separate entities through which larger systems can be understood by analysis. Western medicine is seen widely as the orthodox modern medicine, while Eastern medicine is often regarded as an alternate and parallel system of medicine. South Africa is a country with a highly heterogeneous population and with its cultural and ethnic diversity offers unique opportunities for investigating these different medical, cultural and religious aspects of mental disorders. In addition, different provisions of the Constitution of the Republic of South Africa 1996 are concerned with culture, language and religion. It is therefore obvious that cultural, linguistic and religious matters are elevated to notable levels of constitutional significance, which justifies and necessitates a discussion of both Western and Eastern medical cultures. However, the scope of this article does not allow for a detailed discussion of Western and Eastern medicine and will therefore focus on Western medicine. See Beaubrun and Bannister "The West Indies" 507-527; Miller "Israel and the Jews" 528-546; Rao "India" 624-649; Havens Approaches 1ff; Conrad Western medical tradition $1 \mathrm{ff}$.

38 The Pharaonic Era dates back to 3100 BC. During this time period Egypt witnessed many aspects of progress and renaissance in all fields. Historians divide the Pharaonic Era into three successive divisions: Old Kingdom, Middle Kingdom and Modern Kingdom. For a discussion of this time period see Midant-Reynes Prehistory of Egypt vi, xi-xiii, 1-15, 37, 65, 160-330; Peden Pharaonic Egypt 2, 9 16, 18, 19, 25, 293-294; Vernus and Yoyotte The Pharaohs 6-12, 52-58, $114 \mathrm{ff}$.

39 The oldest yet discovered papyrus is the 'Kahun Gynaecology Papyrus', dating back to $1825 \mathrm{BC}$, during the reign of Amnemhat III. It describes methods of diagnosing pregnancy and the sex of the fetus, toothache during pregnancy, diseases of women, as well as feminine drugs, pastes and vaginal applications. It mainly deals with gynaecological matters and refers to the subject of 'hysteria', attributing it to displacement of the uterus. The most famous 'Edwin Smith papyrus', and to a lesser extent the 'Ebers papyrus', provide a very favourable idea of the medicine, anatomy, and physiology of the Egyptians, and of the scientific outlook that they obtained at least 2000 years before Hippocrates. See Todd 1921 Am Anthropologist 463; Ritner 2000 JNES 108-109.

40 Organic disorders refer to disorders involving a physical lesion in an organ or body part (from Greek organikos meaning of or pertaining to an organ, from organon meaning an implement, from ergein, meaning to work). See Mohit 2001 EMHJ 336; Colman (n 24) 533. For in depth discussions of the history of Egypt and Mesopotamia see Diringer Book before printing 106ff; Verbrugghe and Wickersham Berossos and Manetho 1ff. 
belief emphasised the psychology of the dead and the nature of the personality thereafter. The individual was considered to be composed of three integral parts: First, the 'khat', which represented the body. Second, the 'ka' that represented the soul of the individual's double and was symbolised by uplifted arms, whose main function was to protect the body of the deceased and finally the 'ba', which symbolised a flying bird carrying the key of eternity. The 'ka' was believed to leave the body after death and reside in heaven, periodically visiting the burial place of the mummified body. ${ }^{41}$

Mental disorders have been recognised in Egypt for millennia from approximately 5000 years ago. In the fourteenth century - approximately 600 years before similar institutions were founded in Europe - the first medical and mental institute was established, in Kalaoon Hospital in Cairo. ${ }^{42}$ Ancient Egyptians did not differentiate between mental and physical illnesses. They believed that despite their manifestations, all diseases had physical causes. Mental disorders were considered to be physical ailments of the heart or uterus, as described in the 'Ebers' and 'Kahun Gynaecology' papyri. These disorders carried no stigma, as there was no demarcation then between psyche ${ }^{43}$ and soma ${ }^{44}$ Of major significance is the fact that the 'Kahun Gynaecology' papyrus included more than 30 prescriptions for a variety of diseases attributed to changes in the womb. Consequently it is concluded that the ancient Egyptians anticipated by ten centuries the Hippocratic teachings on the pathogenesis of

41 Okasha 2001 EMHJ 377, 378.

42 This institute was established by the Sultan al-Mansour Kalaoon in 1284 AD. It contained sections for surgery, ophthalmology, medical and mental illnesses. Two features were striking: The care of mental patients in a general hospital and the involvement of the community in the welfare of these patients. According to Okasha these features foreshadowed modern trends by many centuries. See Okasha and Arboleda-Flórez et al Ethics, culture, and psychiatry 23ff; Okasha 2004 Br J Psychiatry 266.

43 Psyche refers to the human mind or soul. In Greek mythology, the soul was personified by Psyche, a young woman who was loved by Eros, the god of love who married her but visited her only at night and insisted that she should never see his face. She symbolises the human soul, suffering, hardship and struggle in life, but re-emerging after death in a new and better existence (from Greek psyche, which means breath, from psychein, which means to breathe, alluding to the ancient belief that breathing was evidence that the soul had not left the body yet). See Colman (n 24) 614.

44 Soma (a cell body) refers to: (1) The central part of a neuron or other cell containing the nucleus and other structures that keep the cell alive. (2) The body of an organism as distinct from its mind, or (in physiology and genetics) as distinct from its germ cells (from Greek soma, which means a body). See Colman (n 24) 710. 
hysteria. ${ }^{45}$ The similarity between some of the ethical precepts of ancient Egyptian physicians and the Hippocratic Oath shows the close connection of the origin between pre-Hippocratic medicine in Greece and Egyptian medicine. It is interesting to note that suicide was not condemned during this time. ${ }^{46}$ One of the recommended treatments for mental disorder was to turn to religion and faith. Suggestion played an important role in all forms of medical treatment, including treatment of the mentally ill, which was associated with Imhotep ${ }^{47}$, the earliest known physician in history. One of the psychotherapeutic methods used in ancient Egypt was 'incubation' or 'temple sleep'. ${ }^{48}$ The course of treatment depended greatly on the manifestations and contents of dreams, which were highly affected by the psycho-religious climate of the temple, or the confidence in the supernatural powers of the deity and on the suggestive procedures carried out by the divine healers. The principal aims of the treatment were knowledge of the sufferer's future, of the dangers that threatened him and of the evil spells that were following him. But he was also

45 See the discussion of hysteria in ancient Greece and Rome below.

46 Suicide as a form of human behaviour is probably as ancient as mankind itself. Views on suicide varied over the centuries and were affected by culture, economy, politics, religion and the intellectual thinking at the time. In primitive cultures suicide was an expression of anger, grief, loss of a loved one, preserving honour or claiming innocence. The argument for and against suicide began in the early stages of human existence and has not come to a conclusion yet. The oldest known written document about suicide was $A$ dispute over suicide also known as Dialogue between a man tired of life and his "ba" which was written by an unnamed Egyptian writer. It is possibly the oldest description of suicidal thoughts and its associated depressive cognition. It was written as a poem between 2000-1740 BC on papyrus in hieroglyphics. The writer is known as the Eloquent Peasant and was commissioned by King Meri-Ka-Re to write a poem in order to dissuade people from committing suicide. The writer ended the argument without any specific conclusion. Pahor and Tadros submit that by doing so, he may have predicted that the argument for and against suicide would always remain unsettled. See Pahor and Tadros 2006 www.ishm2006.hu/. For further reading on this issue, see O'Mathuna and Amundsen 1999 Notre Dame JLEPP 473-496.

47 Imhotep (he who comes in peace), was the physician vizier of the Pharaoh Zoser, founder of the Third Dynasty, in the $13^{\text {th }}$ century. He was a learned man - astronomer, physician and architect. In later times he was worshiped as a hero, as a blameless physician, and later still as the god of medicine, the prototype of Asclepios. Little is known about Imhotep's medical knowledge but his apotheosis is significant and we may well take him at the Egyptian valuation as the first great man in medicine. See Turnure 1952 Record of the Art Museum 26, 27; Linzey "The Duplicity of Imhotep Stone" $1984 \mathrm{~J}$ Architectural Edu 260.

48 A suppliant, on presenting himself to one of the priests, would be assigned a place in the temple to spend the night. While the sufferer was sleeping, Imhotep would supposedly appear to him in a dream and recommend a cure. Should Imhotep fail to appear, or should the patient be unable to sleep, a priest would substitute for the deity, evidently without complaint from the patient. Incubation is characterised by creative thinking while the problem is turned over in the mind, often unconsciously. See Turnure (n 45) 27, 28; Colman (n 24) 371. 
seeking a cure for his ailments. The principle of the healing dreams was attributed to Isis, ${ }^{49}$ although many other deities in Egypt also possessed the same powers. ${ }^{50}$

The reputation of Egyptian physicians ${ }^{51}$ was consistently high throughout Egypt and the rest of the Mediterranean world. Among these were Iry, called 'Keeper of the King's Rectum', a court physician who, about 2500 BC attended to diseases of the eye and belly as well as the anus. Hawi was an Old Kingdom healer of the teeth and anus. The standards of training and of practice seem to have been set by the pharaoh's physician (Great of the palace doctors), who stood at the apex of the hierarchy. Beneath him were the palace physicians (the Egyptian term is saw, meaning 'guardian'), among whom one may have been the supervisor of physicians. The others were inspectors of physicians, a group of lesser chief physicians, and a lower order of physicians comprising the great bulk of practitioners. There were also physicians who took care of workmen and a special cadre of doctors for miners (the Egyptian term is wabw, meaning 'pure of the goddess Sekhmet'). Temple physicians (the Egyptian term is swnw meaning 'doctor of people'), possibly of lower social standing, were available to all people and visited patients' homes as well. Army physicians accompanied military expeditions and gave service to soldiers in the barracks. $^{52}$

49 Isis was worshipped by the Egyptians, who affirm that she discovered many drugs, and was versed in healing, giving aid during sleep while standing above the sick. They say that many who had lost the use of their eyes, or other part of their body, were restored to their previous condition whenever they turned for help to Isis. See Magie $1953 \mathrm{Am} \mathrm{J}$ of Arch $167 \mathrm{ff}$.

50 Okasha (n 41) 378.

51 Egyptian physicians were also priests. It was common for different priests to act as physicians for different parts of the body, in much the same way that doctors specialise now, as they believed that different gods governed different sectors of the human body. The great number of persons who practiced medicine in Egypt was mentioned by Herodotus, a Greek historian who is regarded as the father of history (484 BC-425 BC). He also noticed the remarkable fact that besides general practitioners, there were many who devoted themselves to special branches of medical science, some being oculists, some dentists, some skilled in treating diseases of the brain, and other for treating diseases of the intestines etc. See Laurie 1893 School Rev 358.

52 This strange combination actually makes embryological sense because the mouth (stomadeum) and the anus (proctodeum) are derived from the same types of tissue systems. For a detailed discussion of this topic see Lyons 2007a www.healthguidance.org/. See also Estes The Medical Skills of Ancient Egypt (1989) 1ff. 
Before these physicians could prescribe any treatment, they had to make a diagnosis $^{53}$ by employing their powers of observation and experience in determining the nature of the illness. He would then refer to the medical papyri to determine the most appropriate course of treatment. Normally this would take the form of an unguent comprised from natural ingredients. In treatment of illnesses drugs were administered and mechanical procedures included incantations to drive out demons. Amulets could ward off illnesses of most kinds, but serious mental disorders required the exorcism of demons. ${ }^{54}$

Although Egyptian physicians were people of high standing, they were not exempted of malpractice suits. They were warned to use only the methods promulgated in authoritarian ancient treatises, for then, even if the results were poor, he would be above reproach. Therefore, if medicine was prepared and administered according to the physicians' teachings, he was exempt from all blame even if the treatment were unsuccessful. However, if he deviated away from the traditional remedies and tried to increase his knowledge through experimentation, he risked taking full responsibility if it failed. Lyons ${ }^{55}$ submits that these principles may have hindered the development of medicine in Egypt. In the Ptolemaic era, ${ }^{56}$ the Greek historian Diodorus Siculus ${ }^{57}$ even recorded

53 Egyptian methods of diagnosis relied on information from the patient, but the actual taking of a detailed patient history had not yet developed. The examination was however complex and included probing of wounds with the fingers and a study of the sputum, urine, faeces and other bodily parts. The pulse was recognised as transmitted by the heart and was carefully checked in different parts of the body. Although these physicians did not state a prognosis, they did make decisions on whether to contend with or avoid treatment. Conditions thought to be hopeless were denied treatment. This attitude of withholding treatment to the incurable was a recurring theme throughout history. Lyons discusses this theme in detail and states this might be due to pragmatism or insensitivity, or maybe just pure honesty. See Lyons 2007a www.healthguidance.org/.

54 Trepanation is not mentioned in any of the medical papyri, but seems to have been performed occasionally using a mallet and chisel. Only fourteen skulls, some healed or partially healed, have been found. High et al 2007 www.egyptologyonline.com/.

55 Lyons 2007a www. healthquidance.org/.

56 Ptolemaic Egypt starts chronologically with Alexander the Great's conquest in $332 \mathrm{BC}$ and ends with the death of Cleopatra VII and the Roman conquest in $30 \mathrm{BC}$. Of the aliens who had come to settle upon Egypt, the ruling race, the Graeco-Macedonians and other Greeks, were the most important element. The largest foreign element after the Greek was the Jewish. For further reading of this time period see Irby-Massie and Keyser Greek science 1-15; Schaps and Katzoff Judaean desert 10-20, 70-92, 149ff.

57 Diodorus Siculus was a Sicilian Greek historian. He wrote, a world history in 40 books, ending it near the time of his death with Caesar's Gallic Wars. See Robathan 1932 Classical Philology 84; Griffiths 1973 Classical Rev 9. 
legislative penalties for methodological innovation by state-supported physicians in the army:

For the [Egyptian] physicians draw their support from public funds and administer their treatments in accordance with a written law which was composed in ancient times by many famous physicians. If they follow the rules of this law as they read them in the sacred book $\ldots$ and yet are unable to save their patient, they are absolved and go unpunished; but if they go contrary to the law's prescriptions in any respect, they must submit to a trial with death as the penalty, the lawgiver holding that but few physicians would ever show themselves wiser than the mode of treatment which had been closely followed for a long period and had been originally prescribed by the ablest physicians. $(1.82 .3)^{58}$

According to Ritner legal protection by reference to "prevailing medical standards" underlies much of modern, as well as ancient medical practice. The Egyptian physician's oral diagnosis ("an illness I shall treat"; "An illness with which I shall contend"; or "an illness not to be treated") may have had similar implications as set out above. ${ }^{59}$ As this passage shows, the Egyptians considered their ancient medical texts to be sacred and binding. These texts, in fact, functioned as a kind of law code, complete with the authority to inflict severe penalties for deviants. Clearly, this Egyptian practice attracted the attention of Greek intellectuals because it illustrated, in microcosm, the collision between traditional wisdom and artistic innovation and, even more importantly, the problematic authority of written rules. ${ }^{60}$

\subsubsection{Ancient Mesopotamia}

The oldest medical text extant found is a cuneiform tablet ${ }^{61}$ from Mesopotamia (a land of Assyrian-Babylonian culture) and the cradle of civilisation. The most

58 Diodorus Siculus 1.82 .3 as quoted in Ritner (n 39) 107; cf Nightingale 1999 Classical Q 116.

59 Ritner (n 39) 107.

60 According to Nightingale the practices of Egyptian doctors raised a number of questions that were being debated in 4th century Athens. Eg, are rules by written law the best kind of government? Should written laws be sovereign over every citizen (including a true expert in political affairs)? Should the laws be subject to alteration? If so, how and when should it be carried out? See Nightingale (n 58) 116, 117.

61 The cuneiform script is one of the earliest known forms of written expression. Cuneiforms were written on clay tablets, on which symbols were drawn with a blunt reed called a 
ancient known Egyptian medical writings date from a later period, but they refer back to texts far older. ${ }^{62}$ In ancient Mesopotamia, illnesses, including mental illnesses were blamed on pre-existing spirits and ghosts. Each disease was attributed to one certain spirit. As such, medicine was a part of magic. Among their primitive forebears, illness was a curse, a punishment by the gods which could be visited on the family and descendants as well as on the sinner who had knowingly or inadvertently violated a moral code. However, according to Lyons there was probably some realisation of non-spiritual causes for illness since physicians were admonished - for ethical reasons - to avoid continuing treatment for incurable diseases. ${ }^{63}$

As previously mentioned, a textual source of evidence concerning the skills of Mesopotamian physicians is to be found from the Law Code of Hammurabi. The practice of medicine was regulated by the state. Halwani ${ }^{64}$ explains that malpractice was recognised and was punishable by law. Hammurabi's Code of Law contained several texts (legislative provisions as well as medical ethical rules) showing the liability of physicians who performed surgery. Carelessness and neglect were punished since provision was made for severe penalties. Physicians were to be held liable for surgical errors and failures. Since the laws only specified liability in connection with surgery ('the use of a knife') he assumes that physicians were not held liable for any non-surgical mistakes or

stylus. The impressions left by the stylus were wedge shaped - giving rise to the name cuneiform. See Postgate Early Mesopotamia 56-60.

62 Most important among the more ancient treatises were: Book on the Vessels of the Heart; The Physician's Secret: Knowledge of the Movement of the Heart; Knowledge of the Heart and Collection on the Expelling of the Wehedu (a toxic principle in the body). See Lyons 2007a www.healthguidance.org/.

63 Mesopotamian physicians depended on divination to uncover the sin committed by a sick person and to learn the expiation demanded by the gods, but they also observed a patient's symptoms to estimate the seriousness of the illness. Recitations, ceremonies, prayers, and sacrifices were common religious means of beseeching the gods for a cure; however, along with these a veritable pharmacopoeia of drugs was used in the treatment of disease. In addition to clay tablets which report illnesses with their symptoms and diagnosis, prognosis, and treatment, others were found that list drugs and their appropriate uses. Furthermore, references to bronze lancets in the Code of Hammurabi and elsewhere indicate the use of instruments in surgical operations, and there have been a few isolated archaeological recoveries of knives. A possible trephine has also been unearthed, but no examples of trepanned skulls have yet been found in Mesopotamia. However, they have been uncovered in nearby Judea, which received its medical knowledge and skills from Mesopotamia. See Lyons 2007b www. healthguidance.org/. 
failed attempts to cure an ailment. The Code for example specified that if a surgeon performed a major operation on a nobleman, with a lancet (barber's knife) and caused the death of that man, or the loss of an eye, they shall cut off his hands. A slave who died because of surgery had to be replaced with another one and if he lost his eye the physician had to pay half the slave's value. Hammurabi also specified fees for lifesaving operations namely ten shekels of silver for a nobleman, five shekels for a poor man and two shekels for a slave.

Amundsen ${ }^{65}$ opines that if the medical regulations of the Code were in fact enforced we can assume that little surgery was practiced during this time. He further remarks that it is reasonable to suspect that the lack of competence on the part of the surgeons was in great part responsible for the promulgation of this type of legislation. ${ }^{66}$

\subsubsection{Ancient Greece and Rome}

The history of psychiatry in ancient Greece and Rome extend over a period of twelve centuries, from the time of $\mathrm{Homer}^{67}$ to the age of the later GraecoRoman physicians and encyclopaedists. ${ }^{68}$ A study of this history is extremely difficult since the field of psychiatry scarcely existed as a defined area of medicine or as a category of knowledge on mental disorders. There was a lack of specialists in the field, no textbooks were written on the topic and no

65 Amundsen "Liability of the Physician" 17.

66 Amundsen (n 65) 17; cf Carstens Aanspreeklikheid 109; Carstens 2004 Fundamina 3; Carstens and Pearmain (n 6) 609.

$67700 \mathrm{BC}$. Homer was the major figure of ancient Greek literature and the author of the earliest and finest epic poems, the Iliad and the Odyssey. Homer believed that mental illness was caused by God's taking of the mind. He further believed that mental life was externally caused, interactional and accessible to public view and further that thought and affect were not differentiated from one another, nor were body and mind. He also stated that disturbance and conflict were caused by external events and that the model of the therapist was the bard with his poetry. He offered no treatment. For a discussion of related topics see Grote History of Greece 196ff; Müller Isocrates 15ff; Blackwood Blackwood's 199ff; Rostovtzeff History 232ff; Robinson (n 21) 19-22; Adkins Merit and responsibility 1ff; Harlan Ancient Greece 1ff; Hooper Greek realities 1ff; Adkins Moral values 1ff; McGlew Tyranny 166, 167; Trundle Greek mercenaries 40ff; Deger-Jalkotzy and Lemos Ancient Greece 101ff.

68 AD 500-600. For discussions of this period see Mahaffy Silver age $1 \mathrm{ff}$; Angus Religious quests 239ff; Starr Ancient Greeks 1ff; Starr Ancient Romans (1971) 1ff; Marcovich Studies 1ff; Arthur and Verhoogt Two faces 1-15, 93-155. 
technical term for psychiatry existed. However, there are two main reasons for examining the history of psychiatry during this time period: First, the final legacy of antiquity in this area namely the writings of Galen ${ }^{69}$ and of summarisers such as Caelius Aurelianus ${ }^{70}$ and Alexander of Tralles $^{71}$ provided the basic framework of medical psychiatric thought and practice that endured through the Middle Ages of Europe and into the Renaissance and persisted as the 'paradigm' for psychiatry well into the nineteenth century. Second, classical antiquity has largely defined our sense of the nature of man, of what is accurate, realistic and vivid in the portrayal of human life. ${ }^{72}$

69 AD 100. Galen was educated as a philosopher. His hometown, Pergamum, was the site of a magnificent shrine of the healing god, Asclepius that was visited by many distinguished figures of the Roman Empire for cures. When he was 16, he chose a career of medicine, which he studied at Pergamum, at Smyrna and finally at Alexandria in Egypt, which was the greatest medical centre of the ancient world. After more than a decade of study, he returned in $A D 157$ to Pergamum, where he served as chief physician to the troop of gladiators maintained by the high priest of Asia. Psychic functions of the brain were considered by Galen to be the foremost cause of mental illness. Treatment consisted of confrontation, humour and exercise. Devotion to Galen's medical teachings led to the adoption four major categories of mental illness namely frenzy, mania, melancholy, and fatuity. Each of these was purportedly caused by an imbalance in the humours. To restore the balance was a goal of the physicians of that time. See Johnson Medico-chirurgical review 311-313; Smith 1880 Dictionary 44, 95, 182ff; Handerson and Baas Outlines 101ff; Sayce and Maspero et al History 88; Van Hook Greek life and thought 148, 277, 279ff; Gomperz Greek thinkers 574-575, 581ff; Duke University Greek, Roman and Byzantine studies 335, 356-359; Persehouse and Wightman Science and the Renaissance 85, 162, 204; Clarke and O'Malley Human brain 22-25; Nancy Renaissance medicine 141ff; Furdell Essays 69-77.

70 AD 400. Caelius Aurelianus was the last of the medical writers of the Western Roman Empire and is usually considered the greatest Greco-Roman physician after Galen. His most famous work, De Morbis Acutis et Chronicis (Concerning acute and chronic diseases), is a thorough exposition of classical medical knowledge. Caelius Aurelianus described gout, motor and sensory paralyses, encephalitis, stammering and speech defects. He distinguished between epileptic seizures and hysterical attacks, and recommended humane treatment of the insane. He left two valuable texts on chronic and acute diseases. See Kaufman 1966 Psychiatric Q 1-33; Temkin Falling Sickness 5-7, 2237, 40-41; Hankinson Galen 217, 224-228, 267ff; Van der Eijk Medicine and philosophy 107-110, 122-135, 264.

71 AD 500. Alexander was the youngest of five famous brothers and he too was a famous physician and once practiced in Rome where he was introduced as one of the greatest scholars from the time of Galen to the Renaissance. He recommended baths, wines, diets, and sedatives for the mentally deranged. See Sarton Introduction ix, 427-334. Nutton 1984 Dumbarton Oaks Papers 3ff; O'Dowd Medications for women 99; Prioreschi History of medicine $57 \mathrm{ff}$.

72 Ducey and Bennett "Ancient Greece and Rome" 1-2. 
With regard to the problems surrounding diagnosis, ${ }^{73}$ etiology ${ }^{74}$ and the treatment of mental disorders "the major models of mind and madness in Greek and Roman thought" and the "social-psychological stresses and strains in Greek and Roman civilisation" are still part of the major issues and controversies in contemporary psychiatry today. Of specific relevance is the notion of the various 'models of madness' (for example medical, social, causation and psychodynamic) as well as the closely related problems of the social and psychological context of mental disorder. ${ }^{75}$

Plato, ${ }^{76}$ in particular, appropriated the idea that philosophy is a quasi-medicine and he sometimes combined this idea with the claim that the Socratic type of dialogue was the most effective method of cure for psychical illness. Of importance is the Charmides, an early Platonic dialogue. Here, Socrates ${ }^{77}$ presented himself as a special kind of doctor, who would not cure the body without the psyche, ${ }^{78}$ and who would not attempt to cure until he has made a

73 Diagnosis refers to the process of identifying a disorder by examining its signs and symptoms (from the Greek word dia (between) and gnosis (knowing)). See Colman (n 24) 207.

74 Etiology (also spelt aetiology) is the cause of a particular disorder or study of the causes of disorders in general (from the Greek words aitia (cause) and logos (discourse or reason)). Etiological discovery in medicine is well known in medical history with reference to Robert Koch, a German bacteriologist (1843-1910). He demonstrated that the tubercle bacillus (Mycobacterium tuberculosis complex) causes the disease tuberculosis that Bacillus anthracis causes anthrax, and that cholera is caused by Vibrio cholerae. This line of thinking and evidence is summarised in Koch's postulates. In general it is a study of the problem of causation in medical disorders, which is still a mystery when it comes to the understanding of the causes of mental illness. For further reading of the background of causation, causality, diagnosis and treatment procedures in natural sciences see Evans Causation and disease 1-226; Colman (n 24) 16; Millon Masters of the mind 1ff.

75 Ducey and Bennett (n 72) 3.

76 Plato (428 BC - 348 BC) was a member of a well established aristocratic family. His real name is said to have been Aristocles. He became a student of Socrates, who remained a friend and teacher until his execution. Plato's writings remain among the richest and most fascinating in all philosophy. See King One hundred philosophers 24-25.

77 Socrates (469-399 BC) was born into the golden age of Athens. Socrates' method was the method of cross-examination. It consisted in asking questions and of bringing out the hidden confusions and absurdities of people's positions. He described himself as helping people to give birth to the truth by their own efforts. He was later charged with helping to corrupt the youth of Athens by neglecting the gods and was found guilty and sentenced to the traditional death penalty namely poison. He died a painful and prolonged death. See King (n 76) 23; Colman (n 24) 344; Potter Characteristics 1-122.

78 Psyche, became gradually equated with the rational in man, especially the abstracting and generalising functions of the mind. A division existed between the rational functions and the irrational, appetitive, or somatic ones. This division was usually presented as between portions of the psyche but might also have been conceptualised as the split between psyche and soma. See Ducey and Bennett (n 72) 12. 
diagnostic examination of the psyche of the patient to see if he possessed selfcontrol or not. The diagnostic test and the proposed 'cure' were conducted in Socrates' distinctive method of questioning dialogue. ${ }^{79}$

Hippocrates ${ }^{80}$ was one of the first writers to challenge the belief in supernatural causes of mental disorders. He coined the term hysteria and thought that the cause of this disorder was due to the uterus wandering around the body in search of children. ${ }^{81}$ He held the belief that the body must be treated as a whole and not just a series of parts. He believed in the natural healing process of rest, a good diet, fresh air and cleanliness. He noted that there were individual differences in the severity of disease symptoms and that some individuals were better able to cope with their disease and illness than others. He claimed that mental disorder had a physiological and natural basis. He described a number of mental conditions in clinical detail (currently known as phobias, mania, depression and paranoia) and was the first physician to

79 According to Gill Socratic therapeutic methods may seem superficially - like a psychotherapeutic dialogue in the modern sense - eg, both types of dialogue required the 'patient' to examine himself closely. But the actual content of the dialogue was a very different one. Instead of exploring the particularities of personal life (especially its emotional aspects), Socratic dialogue examined a person's capacity for defining abstract ideas. Given the Socratic tendency to identify moral excellence with knowledge, this procedure makes sense, but it means that Socratic dialogue was a quite different kind of technique from modern psychotherapy. See Gill $1985 \mathrm{~J}$ Hist Ideas 321.

80 Hippocrates (460 BC- 370 BC) was a Greek physician born on the island of Cos (also spelt Kos), Greece. He became known as the founder of medicine and was regarded as the greatest physician of his time. He based his medical practice on observations and on the study of the human body. He travelled throughout Greece practicing his medicine. He founded a medical school on the island of Kos and began teaching his ideas. He soon developed an Oath of Medical Ethics for physicians to follow. Today this Oath is still taken by physicians as they begin their medical careers. Hippocrates is well known as the 'Father of Medicine'. See Hippocrates Genuine Works 131ff; Jones 1909 Am J of Nurs 256-260; Hippocrates Hippocrates 1ff; Bulger and Barbato 2000 Hast CR S4-S7; Goldberg Hippocrates $1 \mathrm{ff}$.

81 As mentioned above, the Egyptian 'Kahun Gynaecology Papyrus' described disturbances resulting from the movement of the uterus but had not yet been given a specific appellation. This step was taken in the Hippocratic writings where the connection of the uterus with the disease resulting from its disturbance was first expressed by the term 'hysteria', which occurred most commonly in virgins and widows. The same general definition (also known as 'female hysteria'), came into widespread use in the middle and late $19^{\text {th }}$ century to describe sexual dissatisfaction. Typical 'treatment' was sexual intercourse (the woman was advised to get married), child-bearing, massage of the patient's genitalia by the physician and later vibrators or water sprays to cause orgasm. For a discussion of hysteria in antiquity, female sexuality as a hysterical pathology, hysteria as a disease paradigm and orgasm treatment in the practice of Western medicine, see Tilt Uterine therapeutics 12ff; King Hippocrates's Woman 21-53, 205-246; Maines Technology of orgasm 22-25, 50-58, 11-113. 
accurately describe the symptoms of pneumonia, as well as epilepsy in children. ${ }^{82}$ He was also the first physician who believed that thoughts, ideas, and feelings came from the brain and not the heart as others of his time.

Undoubtedly these Hippocratic notions are based on bona fide scientific and clinical observations about madness with obvious concurrent physical disease. It is understandable then why the physician should have been prone to ascribe all madness to physical and physiological causes. It is evident that the history of madness in ancient Greece presents the first attempts at a classification of mental disorders. Treatment was essentially physical, sometimes psychological and always empirical. Although its successes did not measure up to those in other branches of Greek medicine it is still of considerable importance, particularly when one considers subsequent achievements in psychiatry. ${ }^{83}$

Both the Greeks and Romans recognised that the mentally disordered were capable of causing social problems as well as harm to themselves or others. Since there were no lunatic asylums, the mentally disordered became a family responsibility and the seriously impaired were restrained at home. Specific laws were passed in which the earliest mention of madmen in Rome occurs in the Twelve Tables:

82 Goodman 2008 www.thecanadianencyclopedia.com/.

83 Other physicians, eg Soranus, Celsus and Aretaeus recognised three mental diseases namely phrenitis, mania and melancholia. According to Drabkin these descriptions would correspond to various modern manic-depressive and schizophrenic forms and also to some severe neuroses, whereas certain milder neuroses might not be recognised as mental diseases at all by ancient medical writers. Ackerknecht opines that neither mania nor melancholia can be recognised as present-day syndromes. Mania simply meant an agitated form of insanity and melancholia a quiet one. For a comprehensive discussion of these physicians and diseases see Ackerknecht (n 9) 15, 16; Singer Short history 119ff; Drabkin 1955 Isis 226-227. It is further interesting to note that a variety of responses to suicide existed in this time period. The importance of shame and honour to these ancient people meant that a distinction between honourable and cowardly suicide was widely recognised. The former was acceptable and even praiseworthy, but the latter was to be condemned. Suicide was often a response to such social pressures as the desire for honour, fear of shame, or simply society's demand for one's self-sacrifice for the good of the whole. For a comprehensive discussion of suicide in ancient times see Dublin Suicide 110ff; Dublin To be, or not to be 1ff; 1991 TAPS 1-34. 
When no guardian has been appointed for an insane person, or a spendthrift, his nearest agnates, or if there are none, his other relatives, must take charge of his property. ${ }^{84}$

This basic law remained virtually the only legal principle applied to madmen throughout the following nine centuries or more. The law of the Twelve Tables formed an important part of the foundation of all subsequent Western civil law. ${ }^{85}$

Furthermore, the Corpus Iuris Civilis made provision for the protection of the rights of the insane person:

The insane, therefore, was to retain not only the ownership of his property for the duration of his illness, but also his position, rank and even his magistracy, if he were a magistrate at the time the illness struck him. However, the law did recognize the juridical capacity of the insane person. He was likened to a person who was absent, asleep or even dead. Consequently, he was considered unable to make a valid will according to the principle of law. Soundness of mind, not health of body, is required of a testator when he makes his will. $^{86}$

Children, because of the innocence of their intentions, and the insane, because of the nature of his or her misfortune, were excused from punishment under the Lex Cornelia. In the matter of legal responsibility or culpability for wrongdoing, the Roman law followed a principle stated in one of the opinions of Paulus, namely that an insane person, like an infant, was incapable of malicious intent

84 Table V Law V11. See Scott Civil Law 67. See also Smith 1875 Dictionary 688-690.

85 The Twelve Tables were written by the Decemviri Consulari Imperio Legibus Scribundis (the 10 Consuls) who were given unprecedented powers to draft the laws of the young Republic. Originally ten laws were drafted. Two later statutes were added prohibiting marriage between the classes and affirming the binding nature of customary law. The new code promoted the organisation of public prosecution of crimes and instituted a system whereby injured parties could seek just compensation in civil disputes. The plebeians were protected from the legal abuses of the ruling patricians, especially in the enforcement of debts. Serious punishments were levied for theft and the law gave male heads of families enormous social power (patria potestas). The important basic principle of a written legal code for Roman law was established and justice was no longer based solely on the interpretation of judges. For a discussion of Roman law see Smith 1878 Dictionary 334ff; Gibbon Roman Empire viff; Cubberley Readings 23ff; Baynes 1932 Greece \& Rome 87ff; Lucilius Remains of old Latin 424-515; Greenidge 1905 EHR 1-21; Steinberg $1982 \mathrm{~J}$ Hist Ideas 379-396; Coleman-Norton 1950 Classical J 127-134. 
and the will to insult. Accordingly he was considered immune from any action for damages. ${ }^{87}$

The ancient Greeks enforced no legal mechanisms whereby the injured patient or relatives of one who had died while under a physician's care could seek legal redress. The treatise entitled Law in the Hippocratic Corpus opens with the assertion that:

Medicine is the most distinguished of all the arts, but owing to the ignorance of those who practise it and of those who rashly judge its practitioners, it is by far inferior to all the other arts. The chief cause of this mistake is that for medicine alone, in the city-states, no penalty has been defined except that of ill repute. But ill repute does not damage those who are compounded of it ... Although many are physicians in name, yet very few are so in reality. ${ }^{88}$

Amundsen ${ }^{89}$ quotes in support of this treatise a fragment of a comedy written by Pliny the Younger ${ }^{90}$ as further evidence: "Only physicians and lawyers can commit murder without being put to death for it." This brings to mind the words of Pliny the Elder, perhaps the most frequently quoted expression of this prejudice:

Additionally, there is no law that would punish capital ignorance, no instance of retribution. Physicians acquire their knowledge from our dangers, making experiments at the cost of our lives. Only a physician can commit homicide with complete impunity. ${ }^{91}$

87 Diamond and Quen Psychiatrist in the Courtroom 39ff.

88 Law in the Hippocratic Corpus as quoted in and translated by Amundsen $1977 \mathrm{~J} \mathrm{Hist} \mathrm{Med}$ \& Allied Sci 172. According to Amundsen both the author and date of this work are unknown. The only ancient author to mention its existence is Erotian (100 AD), a grammarian and physician who lived under the reign of Nero. Jones WHS, the translator of Hippocrates for the Loeb Classical Library, finds a Stoic influence in the work but often no suggestion as to date: The piece is too short for this historian to base any argument upon general style or subject matter. See further Barnes Early Greek philosophy $217 \mathrm{ff}$.

89 Amundsen (n 88) 173.

90 Gaius Plinius Caecilius Secundus (Pliny the younger, adopted by his uncle, Pliny the Elder) (AD 61 - c 113) was a Roman author and administrator who left a collection of private letters of great literary charm, intimately illustrating public and private life in the heyday of the Roman Empire. He practiced law from the age of 18. His reputation in the civil-law courts placed him in demand in the political court that tried provincial officials for extortion. Amundsen (n 88) 173. See also Pliny Select letters 9-88.

91 Gaius Plinius Secundus (Pliny the Elder), (23-79 AD), was an ancient author, natural philosopher and a naval and military commander and also the author of Naturalis Historia. He believed that: "True glory consists of doing what deserves to be written, and writing 
It is interesting to note that in the lack of penalties for malpractice in Greece an important difference is noticed from the professional discipline in the present.

The Romans had developed the distinctions between dolus (evil intent), culpa (including both negligence (neglegentia) and incompetence (imperitia)), and casus (accident). Dolus falls under intentional action, but culpa and casus generally under unintentional action. Both negligent malpractice and incompetent malpractice were classified under the concept of culpa. ${ }^{92} \mathrm{~A}$ considerable overlap exists between these areas of law and Roman jurists struggled with the intricacies of the application of these principles. ${ }^{93}$ According to the rule imperitia culpae adnumeratur, ignorance or incompetence (of for example physicians) was regarded as negligent malpractice. This rule was applied where a physician performed an operation in an unskilled manner, and also where a physician prescribed the wrong medication to a patient. ${ }^{94}$ Carstens explains that the proof of medical negligence in Roman law was problematic as it is not mentioned in the available source literature. He submits that it can, however, be accepted that the onus of proof in cases of medical negligence was on the plaintiff who had to proof that the alleged negligence by the physician caused personal injury. ${ }^{95}$

The imperitia culpae adnumeratur rule of the Roman law also found application in the Roman-Dutch law when the negligent or ignorant conduct of a physician was assessed. De Groot ${ }^{96}$ commented as follows:

what deserves to be read." See Amundsen (n 88) 173. See also Merrill 1910 Classical Philology $175 \mathrm{ff}$.

92 Buckland Textbook 556ff.

93 Amundsen (n 88) 174.

94 Digest: Ad Legem Aquiliam 501732 "(Gaius 7 Ad Edictuum Provinciale): Imperitia Culpae Adnumeratur"; Inst Just 43 7: "Imperitia culpae adnumeratur, veluti si medicus ideo servum tuum occiderit, quod eum male secuerit aut perperam ei medicamentum dederit"; D 9278 "(Ulpianus 18 Ad Edictum) Proculus ait, si medicus servum iperite secuerit vel ex locato vel exlege Aquilia competere actionem"; D 9278 "(Gaius 7 Ad Edictum Provinciale): Idem iuris est si medicamento perperam usus fuerit".

95 Carstens and Pearmain (n 6) 614.

96 1583-1645. Grotius Inleidinge tot die Hollandsche Rechts-Geleerdheid 333 5. Carstens also discusses the application of this rule. See Carstens and Pearmain (n 6) 616. See also Scott "Nalatigheidstoets" 134. 
Dat de dood door iemands schuld toegekomen, waer onder mede begrepen is verzuim ofte onwetenheid van een geneesmeester, vroedwijf, verzuim ofte onverstand van een waghanaer ofte schipper, of der zelver zwackheid in't bestieren van schip ofte paerden.

Carstens explains that the Dutch concepts of onwetenheid, onverstand and zwackheid, in context of legal liability, were equated to the concept of fault, which implies a repetition of the position in Roman law. ${ }^{97}$ According to van Leeuwen it is disputed of whether a physician would be punishable for giving medicine to a patient, which has done him harm, or caused his death, trough the physician's neglect and ignorance. ${ }^{98}$ Because many amendments are made in law, a physician would probably have been punished according to the discretion of the court.

With regard to the imposition of severe penalties on physicians in instances where patients died as a result of medical negligence, Voet $^{99}$ remarked as $^{2}$ follows:

Dum affectare nemo debet id, in quo vel intelligit vel intelligere debet, imperitiam suam aut infirmitatem alteri periculosam futuram, consequens est ut hac quoque lege teneatur medici, pharmacopolae, obstetrics, imperite secants, perperam medicamenta venena propinantes, supponentes infundentes, pro medicamentis venena dantes.

The free translation reads as follows:

While nobody has the right to claim to do something when he understands or ought to understand that his inexperience or infirmity may be dangerous to another person, it follows that the following people will be liable in terms of this rule: physicians, pharmacists, midwives, those who without experience perform surgery, those who erroneously administer poisonous medicine or administer poison instead of medication. ${ }^{100}$

97 Carstens and Pearmain (n 6) 616.

98 Van Leeuwen and Isaakszoon Commentaries 494.

99 Johannes Voet (1647-1713). Carstens and Pearmain (n 6) 617; Scott (n 96) 136 n 91. See further s 134 of the Constitutio Criminalis Carolina of 1532.

100 Carstens and Pearmain (n 6) 617; Scott (n 96) 136 n 91. See further s 134 of the Constitutio Criminalis Carolina of 1532. 


\section{The Canons}

The canons, regulating the internal church relationships, were based on scriptural authority, conciliar decisions and papal decretals. The Roman law tradition made itself felt on the emerging canon law from fairly early times. ${ }^{101}$ The Corpus luris Canonici ${ }^{102}$ is the collection of significant sources of canon law of the Catholic Church ${ }^{103}$ that was applicable to the universal church or specifically to churches of the Latin Rite or Eastern Rites. ${ }^{104}$ It was replaced by the Codex luris Canonici, ${ }^{105}$ which was promulgated in 1917 and went into effect in 1918.

Although literature sources with regard to psychiatry as well as to the incidences of medical negligence are limited, Canon law proscribed most 'insane' thoughts and behaviour long before they came to be regarded by medical science as indicators of possible mental disorder. The Corpus Iuris Canonici contains a decree prohibiting secular clerics and regulars from attending public lectures at the universities in medicine and law. ${ }^{106}$ As to the practice of medicine by clerics, the Fourth Council of the Lateran (1215) forbade its employment when cutting or burning was involved. In the decree ${ }^{107}$ it is said: "Let no subdeacon, deacon or priest exercise any art of medicine

101 Edwards South African law 20.

102 Translated as: Body of Canon law. See Bouvier and Rawle Dictionary 417.

103 Such as those in each diocese and in the courts of appeal at the Vatican (such as the Sacra Rota Romana). For an in depth discussion of the Canonical doctrine and legislation, see Burke 1985 Jurist 171ff.

104 Borkowski and Du Plessis Textbook 364.

105 Translated as: Code of Canon law. See Coriden An introduction to Canon Law (2004) xi, xii, 4, 24-29.

106 (cap. Nam magnopere, 3, Ne clerici aut monachi.) The reason adduced is, lest through such sciences, spiritual men be again plunged into worldly cares. They were not hereby forbidden to make private studies in medicine or to teach it publicly. The Council of Tours (1163), in issuing a similar prohibition, had especially in view, monks who left their cloisters under pretext of attending university lectures, and in this were imitated by secular priests, who thus violated their obligations of residence. This law was extended by Honorius III to all clerics having ecclesiastical dignities. It is not binding, consequently, on the lower clergy, or on those clerics who pursue the sciences only as private studies. The penalty imposed for violation was excommunication ipso facto. Fanning Original Catholic Encyclopedia 142.

107 (c. Sententiam 9, Ne cler. vel mon,) as referred to by Fanning (n 106) 142. 
which involves cutting or burning." This was especially prohibited to regulars, ${ }^{108}$ and they are also forbidden to exercise the science of medicine in any form. ${ }^{109}$ This general prohibition is extended to all clerics, inasmuch as the art of medicine is of its nature secular and, moreover, involves the danger of incurring an irregularity. ${ }^{110}$ Canonists, however, generally hold that in case of necessity and where danger to life is not involved, clerics can practise medicine through pity and charity towards the poor, in default of ordinary practitioners.

Physicians who prescribed remedies involving infractions of the Decalogue were themselves guilty of grave sin. This was also the case if they experimented on a sick person with unknown medicines, unless all hope has been given up and there was at least a possibility of doing them good. Physicians were to be reminded that they had no dispensing power concerning the fast and abstinence prescribed by the Church. They, however, might have given their prudent judgment as to whether a sick person, owing to grave danger or inconvenience to his health, was obliged by the ecclesiastical precept. They were warned that, if they declared unnecessarily that a person was not obliged to fast, they themselves committed grave sin. They also sinned mortally if their attempt - without being forced by necessity - to cure a serious illness, is the cause of grave harm to the patient through their own culpable ignorance or inexperience. ${ }^{111}$

\section{Conclusion}

In summary, it is clear that history strongly links law, medicine and psychiatry. This history had a long evolution, as had other branches of medicine. Psychiatry is a discipline concerned with the healing of the psyche, but ignorance of pathology and psychopathology led to unclear differentiation of psychic and somatic syndromes - particularly when the latter have given rise to 
states not always easy to differentiate from psychic states, for example, the excitement of delirium and the agitation of acute anxiety. Hippocrates made this essential mistake in seeing insanity and emotional illness as both arising from the brain and affected by the equilibrium of the humours. This confusion is as well marked today in medicine as it was in antiquity. Throughout history the legal care of the mentally disordered patient has also been influenced by the legal enactments of the past. A fundamental question that arose from this article is: Does the history of law and psychiatry suggest any means by which we can make progress in future? This article emphasises the message as would the history of any subject. Advance depends on knowledge, knowledge depends on careful observation, observation leads to worthwhile theories and theories need to be proved by systematic enquiry. But the fact remains that when making cross comparisons between regions of the world, the reader must be struck by the fact that so many views and practices are held in common. ${ }^{112}$ The most common explanation for these similarities are that conquering people carry their moves with them and even impose them on the conquered, particularly if they improve on the native practice, and therefore the happiest thought for the present generation of psychiatrists is the extent of the undiscovered - their age is yet to come. ${ }^{113}$

113 As Shakespeare said: "Things won are done: joy's soul lies in the doing." See Troilus and Cressida, I, ii, 313. 


\section{Bibliography}

Amundsen "Liability of the Physician"

Amundsen DW "The Liability of the Physician in Roman Law" in Karplus H (ed) International Symposium on Society, Medicine and Law, Jerusalem, March 1972 (Elsevier Amsterdam 1973)

Amundsen 1977 J Hist Med \& Allied Sci

Amundsen DW "The Liability of the Physician in Classical Greek Legal Theory and Practice" 1977 Journal of the History of Medicine and Allied Sciences 172-203

Ackerknecht 1947 Am Anthropologist

Ackerknecht EH "Primitive surgery" 1947 (49) American Anthropologist 2545

Ackerknecht Psychiatry

Ackerknecht EH Short history of psychiatry (Hafner Publishing Company New York London 1968)

Adkins Merit and responsibility

Adkins AWH Merit and responsibility (Clarendon Press Oxford 1960)

Adkins Moral values

Adkins AWH Moral values and political behaviour in Ancient Greece: From Homer to the end of the Fifth century (WW Norton New York 1972)

Angus Religious quests

Angus S The religious quests of the Graeco-Roman world: A study in the historical background of early Christianity (Biblo \& Tannen New York 1967)

Arthur and Verhoogt Two faces

Arthur MFW and Verhoogt S (eds) The two faces of Graeco-Roman Egypt: Greece and demotic and Greek-demotic texts and studies (Brill Leiden 1998)

Barnes Early Greek philosophy

Barnes J Early Greek philosophy (Penguin Books London 2001) 
Bartlett 2001 Soc Hist Med

Bartlett P "Legal madness in the nineteenth century" 2001 (14) Social History of Medicine 107-131

Baynes 1932 Greece \& Rome

Baynes NH "On teaching the history of the Roman Republic" 1932 (1)

Greece \& Rome 87-95

Beaubrun and Bannister "The West Indies"

Beaubrun MH and Bannister P "The West Indies" in Howells JG (ed) World history of psychiatry (Brunner/Mazel New York 1975) 507-527

Blackwood Blackwood's

Blackwood W Blackwood's Edinburg Magazine (Leonard Scott New York 1856)

Borkowski and Du Plessis Textbook

Borkowski A and Du Plessis P Textbook on Roman Law 4th ed (Oxford University Press Oxford 2005)

Bouvier and Rawle Dictionary

Bouvier J and Rawle F Bouvier's Law Dictionary and Concise Encyclopedia (Vernon Law Book St Paul Minn 1914)

Brand 1970 J Contemp Psycotherapy

Brand M "Is mental illness a myth?" 1970 (3) Journal of Contemporary Psychotherapy 13-17

Broman 1989 Osiris

Broman T "University reform in medical thought at the end of the eighteenth century" 1989 (5) Osiris 36-53

Buckland 1882 JAIGBI

Buckland AW "Surgery and superstition in Neolithic times" 1882 (11)

Journal of the Anthropological Institute of Great Britain \& Ireland 7-21 
Buckland Textbook

Buckland AW A textbook of Roman Law from Augustus to Justinian

(Cambridge University Press Cambridge 1950)

Bulger and Barbato 2000 Hast CR S4-S7

Bulger RJ and Barbato AL "On the Hippocratic Sources of Western Medical Practice" 2000 Hastings Center Report S4-S7

Burke 1985 Jurist

Burke RL "Lack of Discretion of Judgment: Canonical Doctrine and Legislation" 1985 The Jurist 171-209

Campbell Masks of God

Campbell J The Masks of God: Primitive Mythology (Penguin New York 1976)

Campbell 1999 Am JFP

Campbell TW "Challenging the evidentiary reliability of DSM-IV" 1999 (17) American Journal of Forensic Psychology 47-68

Carstens 2004 Fundamina

Carstens PA "Regshistoriese perspektiewe oor die oorsprong en ontwikkeling van mediese nalatigheid" 2004 (10) Fundamina 1-16

Carstens Aanspreeklikheid

Carstens PA Die strafregtelike en deliktuele aanspreeklikheid van die geneesheer op grond van nalatigheid (LLD-thesis UP 1996)

Carstens and Pearmain Foundational principles

Carstens PA and Pearmain DL Foundational principles of South African medical law (LexisNexis Durban 2007)

Cawte Medicine

Cawte $\mathrm{J}$ (ed) Medicine is the law: Studies in psychiatric anthropology of Australian tribal societies (University Press of Hawaii Honolulu 1974) 
Clark and Crawford Legal Medicine

Clark M and Crawford C Legal Medicine in History (Cambridge University Press Cambridge 1994)

Clarke and O'Malley Human brain

Clarke E and O'Malley CD The human brain and spinal cord: A historical study illustrated by the writings from antiquity to the twentieth century (Norman California 1996)

Coleman-Norton 1950 Classical J

Coleman-Norton PR "Cicero's Contribution to the Text of the Twelve Tables" 1950 Classical Journal 127-134

Colman Dictionary of psychology

Colman AM Oxford dictionary of psychology (Oxford University Press

Oxford New York 2006)

Conrad Western medical tradition

Conrad LI The western medical tradition (Cambridge University Press London 1995)

Cubberley Readings

Cubberley EP Readings in the History of Education: A Collection of Sources and Readings to Illustrate the Development of Educational

Practice, Theory, and Organization (Houghton and Mifflin Boston1920)

Deger-Jalkotzy and Lemos Ancient Greece

Deger-Jalkotzy S and Lemos IS (eds) Ancient Greece: From the Mycenaean palaces to the age of Homer (Edinburgh University Press Edinburgh 2006)

Demetrio 1978 Asian Folklore Studies

Demetrio FR "The Shaman as psychologist" 1978 (37) Asian Folklore Studies $57-75$ 


\section{DeWitt 1947 Classical J}

DeWitt NW "Epicurus: Philosophy for the millions" 1947 (42) Classical Journal 195, 197-201

Diamond and Quen Psychiatrist in the Courtroom

Diamond BL and Quen JM The Psychiatrist in the Courtroom: Selected Papers of Bernard L Diamond (Analytic Press Hillsdale NJ 1994)

Diringer Book before printing

Diringer D The book before printing: Ancient, medieval and oriental (Courier Dover New York 1982)

Drabkin 1955 Isis

Drabkin IE "Remarks on Ancient Psychopathology" 1955 Isis 223-234

Dublin Suicide

Dublin LI Suicide: A sociological and statistical study (The Ronald Press New York 1882)

Dublin To be, or not to be

Dublin LI To be, or not to be: A study of suicide (Smith \& Haas New York 1993)

Ducey and Bennett "Ancient Greece and Rome"

Ducey C and Bennett S "Ancient Greece and Rome" in Howells JG (ed) World history of psychiatry (Brunner/Mazel New York 1975) 1-38

Duke University Greek, Roman and Byzantine studies

Duke University Greek, Roman and Byzantine studies (Duke University Press Durham 1959)

Duncan 1904 Bib'l World

Duncan GS "The Code of Moses and the Code of Hammurabi" 1904 (23)

Biblical World 188-193

Edwards South African law

Edwards AB The History of South African law - An Outline (Butterworths Durban 1998) 


\section{Estes Medical skills}

Estes JW The medical skills of ancient Egypt (Canton Massachusetts 1989)

Evans Causation and disease

Evans AS Causation and disease: A chronological journey (Springer New York 1993)

Fanning Original Catholic Encyclopedia

Fanning W The Original Catholic Encyclopedia: Medicine and Canon Law

(Robert Appleton New York 1911)

Feldman and Goodrich 2001 Neurosurgery

Feldman R and Goodrich J "Psychosurgery: A historical overview" 2001

(48) Neurosurgery 647-659

Furdell Essays

Furdell EL Essays on Medieval and Early Modern medicine (Brill Leiden 2005)

Garrison 1991 TAPS

Garrison EP "Attitudes towards suicide in ancient Greece" 1991 (121)

Transactions of the American Philological Society 1-34

Gibbon Roman Empire

Gibbon E The History of the Decline and Fall of the Roman Empire (John Murray London 1881)

Gill $1985 \mathrm{~J}$ Hist Ideas

Gill C "Ancient psychotherapy" 1985 (46) Journal of the History of Ideas 307-325

Greenidge 1905 EHR

Greenidge AHJ "The Authenticity of the Twelve Tables" 1905 English Historical Review 1-21

Goldberg Hippocrates

Goldberg HS Hippocrates: Father of medicine (iUniverse USA 2006) 


\section{Gomperz Greek thinkers}

Gomperz T Greek thinkers: A history of ancient philosophy (Scribner New York 1905)

Griffiths 1973 Classical Rev

Griffiths JG "Diodorus Siculus i. 22. 4 f" 1973 (23) Classical Review 9

Grote History of Greece

Grote G A history of Greece (Murray London 1846)

Guharaj Forensic Medicine

Guharaj PV Forensic Medicine (Orient Longman India 2003)

Halwani and Takrouri 2007 IJLH\&E

Halwani TM and Takrouri MSM "Medical laws and ethics of Babylon as read in Hammurabi's code (history)" 2007 (4) Internet Journal of Law, Healthcare and Ethics 2-7

Handerson and Baas Outlines

Handerson $\mathrm{HE}$ and Baas JH Outlines of the history of medicine and the medical profession (Vail JH \& Company New York 1889)

Hankinson Galen

Hankinson RJ Galen: On antecedent causes: Cambridge classical texts and commentaries (Cambridge University Press New York 1998)

Harlan Ancient Greece

Harlan W The horizon book of ancient Greece (American Heritage New York 1965)

Harland Geological timescale

Harland WB A geological timescale 1989 (Cambridge University Press Cambridge 1990)

Havens Approaches

Havens LL Approaches to the mind (Little Brown Boston 1973) 


\section{Hippocrates Hippocrates}

Hippocrates Hippocrates (translated from the original by JET Withington)

(Harvard University Press Cambridge 1948)

Hippocrates Genuine works

Hippocrates The genuine works of Hippocrates (translated from the original

by F Adams) (Adlard Printers London 1849)

Hooper Greek realities

Hooper F Greek realities: Life and thought in ancient Greece (Scribner New York 1967)

Howells World history

Howells JG (ed) World history of psychiatry (Brunner/Mazel New York 1975)

Hunt and Mesquita 2006 HRQ

Hunt $P$ and Mesquita J "Mental Disabilities and the Human Right to the Highest Attainable Standard of Health" 2006 (28) Human Rights Quarterly 335-356

Irby-Massie and Keyser Greek science

Irby-Massie GL and Keyser PT Greek science of the Hellenistic era: $A$ source book (Routledge London 2002)

Johnson Medico-chirurgical review

Johnson HJ The medico-chirurgical review (Wood \& Wood New York 1847)

Jones 1909 Am J of Nurs

Jones MC "The Hippocratic Oath" 1909 (9) American Journal of Nursing 256-260

Kaplan and Sadock Psychiatry

Kaplan HI and Sadock BJ (eds) Comprehensive text book of psychiatry (Williams \& Wilkins Baltimore 1985) 
Karplus International symposium

Karplus H (ed) International symposium on society, medicine and law, Jerusalem, March 1972 (Elsevier Scientific Amsterdam 1973)

Kaufman 1966 Psychiatric Q

Kaufman MR "The Greeks had some words for it: Early Greek concepts on mind and 'insanity"' 1966 (40) Psychiatric Quarterly 1-33

Kerley and Bass 1967 Science

Kerley ER and Bass WM "Paleopathology: Meeting ground for many disciplines" 1967 (157:3789) Science New Series 638-644

King Hippocrates's Woman

King $\mathrm{H}$ Hippocrates's Woman: Reading the Female Body in Ancient Greece (Routledge London 1998)

King One hundred philosophers

King PJ One hundred philosophers: A guide to the world's greatest thinkers (Zebra Press Cape Town 2004)

Laurie 1893 School Rev

Laurie SS "The history of early education II: The ancient Egyptians" 1893

(1) School Review 353-364

Linzey MPT "The duplicity of Imhotep stone" $198448 \mathrm{~J}$ Architectural Edu 4:

260-267

Lucilius Remains of old Latin

Lucilius Remains of old Latin: Lucilius: The Twelve Tables (translated from the original by EH Warmington) (Harvard University Press Massachusetts 1938)

Lyon $1906 \mathrm{~J}$ Am Oriental Society

Lyon DG "When and where was the Code of Hammurabi promulgated?" 1906 (27) Journal of the American Oriental Society 123-134 
Magie 1953 Am J of Arch

Magie D "Egyptian deities in Asia minor in inscriptions and on coins" 1953

(57) American Journal of Archaeology 163-187

Magner History of medicine

Magner LN A history of medicine (Dekker New York 1992)

Mahaffy Silver age

Mahaffy JP The silver age of the Greek world (Adamant Media London 1906)

Maines Technology of orgasm

Maines RP The technology of orgasm: Hysteria, the vibrator and women's sexual satisfaction (John Hopkins University Press Baltimore Maryland 2001)

Marcovich Studies

Marcovich M Studies in Graeco-Roman religions and Gnosticism (Brill Leiden 1988)

Massengill Sketch

Massengill SE $A$ sketch of medicine and pharmacy (Bristol Tennessee 1943)

McGlew Tyranny

McGlew JF Tyranny and political culture in ancient Greece (Cornell University Press New York 1996)

Merrill 1910 Classical Philology

Merrill ET "On the eight-book tradition of Pliny's letters in Verona" 1910 (5) Classical Philology 175-188

Midant-Reynes Prehistory of Egypt

Midant-Reynes B The prehistory of Egypt: From the first Egyptians to the first Pharaohs (Blackwell London 2000) 
Miller "Israel and the Jews"

Miller N "Israel and the Jews" in Howells JG (ed) World history of psychiatry (Brunner/Mazel New York 1975) 528-546

Millon Masters of the mind

Millon T Masters of the mind: Exploring the story of mental illness from ancient times to the new millennium (Wiley \& Sons Hoboken New Jersey 2004)

Mohit 2001 EMHJ

Mohit A "Mental health and psychiatry in the Middle East: Historical development" 2001 (7) Eastern Mediterranean Health Journal 336-347

Moodie 1918 Science

Moodie RL "Synthesis of palaeontology and medical history" 1918 (48:1251) Science New Series 619-620

Mora "History of Psychiatry"

Mora G "History of Psychiatry" in Kaplan HI and Sadock BJ (eds)

Comprehensive Text Book of Psychiatry (Williams \& Wilkins Baltimore MD 1985) 2034-2054

Müller Isocrates

Müller KO History of the literature of ancient Greece: To the period of Isocrates (Baldwin London 1847)

Nancy Renaissance medicine

Nancy G The clock and the mirror: Girolamo Cardano and Renaissance medicine (Princeton University Press Princeton 1997)

Nightingale 1999 Classical Q

Nightingale AW "Plato's lawcode in context: Rule by written law in Athens and Magnesia" 1999 (49) Classical Quarterly 100-122

Nutton 1984 Dumbarton Oaks Papers

Nutton $\vee$ "From Galen to Alexander, aspects of medicine and medical 
practice in late antiquity" (Symposium on Byzantine Medicine) 1984 (38) Dumbarton Oaks Papers 1-14

Oakley et al 1959 Man

Oakley KP et al "Contributions on trepanning or trephination in ancient and modern times" 1959 (59) Man 93-96

O'Dowd Medications for women

O'Dowd MJ The history of medications for women: Materia medica woman (Informa Health Care London 2001)

Okasha 2001 EMHJ

Okasha A "Egyptian contribution to the concept of mental health" 2001 (7) Eastern Mediterranean Health Journal 377-380

Okasha 2004 Br J Psychiatry

Okasha A "Focus on psychiatry in Egypt" 2004 (185) British Journal of Psychiatry 266-272

Okasha and Arboleda-Flórez et al Ethics, culture, and psychiatry

Okasha A and Arboleda-Flórez J et al (eds) Ethics, culture, and psychiatry: International perspectives (American Psychiatric Press Washington 2000)

O'Mathuna and Amundsen 1999 Notre Dame JLEPP

O'Mathuna DP and Amundsen DW "Historical and Biblical references in physician-assisted suicide court opinions" 1999 (12) Notre Dame Journal of Law, Ethics \& Public Policy 473-496

Peden Pharaonic Egypt

Peden AJ The graffiti of Pharaonic Egypt: Scope and roles of informal writings (c.3100-332 BC) (Brill Leiden 2001)

Perrin 2003 Antiquity

Perrin T "Mesolithic and Neolithic cultures co-existing in the upper Rhône valley" 2003 (77:298) Antiquity 732-739 
Persehouse and Wightman Science and the Renaissance

Persehouse W and Wightman D Science and the Renaissance (Hafner New York 1962)

Pfeiffer 1920 Am J Sem L\&L

Pfeiffer RH "An analysis of the Hammurabi Code" 1920 (36) American

Journal of Semitic Languages \& Literatures 310-315

Platt and Diamond 1966 Cal LR

Platt $A$ and Diamond $B L$ "The origins of the right and wrong test of criminal responsibility and its subsequent development in the United States: An historical survey" 1966 (54) California Law Review 1227-1260

Pliny Select letters

Pliny Select letters of Pliny the younger (with notes): Illustrative of the manners, customs, and laws of the ancient Romans (Perkins Marvin Boston 1835)

Postgate Early Mesopotamia

Postgate JN Early Mesopotamia: Society and economy at the dawn of history (Routledge New York 1994)

Potter Characteristics

Potter JP Characteristics of the Greek philosophers: Socrates and Plato (Parker London 1845)

Price 1932 J Am Oriental Soc

Price IM "The relation of certain gods to equity and justice in early Babylonia" 1932 (52) Journal of the American Oriental Society 174-178

Price 1904 Bib'l World

Price IM "The stele of Hammurabi" 1904 (24) Biblical World 468-472

Prince $1910 \mathrm{~J}$ Bib'l Lit

Prince JD "The name Hammurabi" 1910 (29) Journal of Biblical Literature 21-23 
Prioreschi History of medicine

Prioreschi P A history of medicine (Horatius Press Omaha 2001)

Quennell and Quennell Everyday life

Quennell M and Quennell CHB Everyday life in prehistoric times (Batsford London 1973)

Rao "India"

Rao V "India" in Howells JG (ed) World history of psychiatry

(Brunner/Mazel New York 1975) 624-649

Richards 1998 Critical Inquiry

Richards RJ "Rhapsodies on a cat-piano, or Johann Christian Reil and the foundations of romantic psychiatry" 1998 (24) Critical Inquiry 700-736

Ritner 2000 JNES

Ritner RK "Innovations and adaptations in ancient Egyptian medicine" 2000 (59) Journal of Near East Studies 107-117

Robathan 1932 Classical Philology

Robathan DM "Diodorus Siculus in the Italian Renaissance" 1932 (27)

Classical Philology 84

Robinson Ancient history

Robinson CA Ancient history from prehistoric times to the death of Justinian (Macmillan Company New York 1951)

Robinson Hellas

Robinson CE Hellas: A short history of ancient Greece (Beacon Press

Boston 1955)

Rostovtzeff History

Rostovtzeff M A history of the ancient world: The Orient and Greece (Biblo

\& Tannen New York 1926)

Sarton Introduction

Sarton G Introduction to the history of science (Williams \& Wilkins

Baltimore Washington 1927) 
Sayce and Maspero et al History

Sayce AH and Maspero G et al History of Egypt, Chaldea Syria, Babylonia, and Assyria (Grolier Society London 1904)

Schaps and Katzoff Judaean desert

Schaps DM and Katzoff R (eds) Law in the documents of the Judaean desert (Brill Leiden 2005)

\section{Scott Civil Law}

Scott SP The Civil Law, including the Twelve Tables, the Institutes of Gaius, the Rules of Ulpian, the Opinions of Paulus, the Enactments of Justinian, and the Constitutions of Leo Vol 1 (Central Trust Company Cincinnati 1932)

Scott "Nalatigheidstoets"

Scott TJ "Die Reël Imperitia Culpae Adnumeratur as Grondslag vir die Nalatigheidstoets vir Deskundiges in die Deliktereg" in DJ Joubert (ed) Petere Fontes - LC Steyn Gedenkbundel (Joubert al 1981) 134-156

Shorter History of psychiatry

Shorter E A history of psychiatry: From the era of the asylum to the age of Prozac (Wiley Toronto 1997)

\section{Singer Short history}

Singer C A short history of medicine: Introducing medical principles to students and non-medical readers (Oxford University Press New York 1928)

Smith 1936 JCL\&C

Smith EJ "Medicine, the law and juvenile delinquency" 1936 (27) Journal of Criminal Law \& Criminology 503-514

Smith 1880 Dictionary

Smith W Dictionary of Greek and Roman biography and mythology (John Murray London 1880) 
Smith 1878 Dictionary

Smith W A dictionary of Greek and Roman Antiquities (John Murray London 1878)

Smith 1875 Dictionary

Smith W A dictionary of Greek and Roman Antiquities (John Murray London 1875)

Starr Ancient Greeks

Starr CG The ancient Greeks (Oxford University Press USA 1971)

Starr Ancient Romans

Starr CG The ancient Romans (Oxford University Press USA 1971)

Stearns and Langer Encyclopedia

Stearns PN and Langer WL (eds) The encyclopedia of world history:

Ancient, Medieval, and Modern, chronologically arranged (Houghton Mifflin Books New York 2001)

Steward 1949 Am Anthropologist

Steward $\mathrm{JH}$ "Cultural causality and law: A trial formulation of the development of early civilizations" 1949 (51) American Anthropologist 1-27

Steinberg 1982 J Hist Ideas

Steinberg M "The Twelve Tables and Their Origins: An Eighteenth Century Debate" 1982 Journal of the History of Ideas 379-396

Stout Psychology of terrorism

Stout CE (ed) The psychology of terrorism: A public understanding

(Praeger Publishers Westport 2002)

Swanepoel Law, Psychiatry and Psychology

Swanepoel M Law, Psychiatry and Psychology: A Selection of

Constitutional, Medico-Legal and Liability Issues (LLD-thesis Unisa 2009)

Swinton Spirituality

Swinton J Spirituality and mental health care: Rediscovering a "forgotten" dimension (Jessica Kingsley Publishers London 2001) 


\section{Temkin Falling Sickness}

Temkin O The Falling Sickness: A History of Epilepsy from the Greeks to the Beginnings of Modern Neurology (Johns Hopkins Baltimore 1994)

Tilley Ethnography of the Neolithic

Tilley CA An ethnography of the Neolithic: Early prehistoric societies in Southern Scandinavia (Cambridge University Press Cambridge 1996)

Tilt Uterine therapeutics

Tilt EJ A hand-book of uterine therapeutics, and of diseases of women (Appleton New York 1869)

Todd 1921 Am Anthropologist

Todd TW "Egyptian medicine: A critical study of recent claims" 1921 (23) American Anthropologist 460-470

Trundle Greek mercenaries

Trundle M Greek mercenaries: From the late archaic period to Alexander (Routledge London 2004)

Turnure 1952 Record of the Art Museum

Turnure JH "A statuette of Imhotep" 1952 (11) Record of the Art Museum, PU 25-28

Van der Eijk Medicine and philosophy

Van der Eijk PJ Medicine and philosophy in classical antiquity: Doctors and philosophers on nature, soul, health and disease (Cambridge University Press Cambridge 2005)

Van Hook Greek life and thought

Van Hook L Greek life and thought: A portrayal of Greek civilisation

(Columbia University Press New York 1923)

Van Leeuwen and Isaakszoon Commentaries

Van Leeuwen S and Isaakszoon C Commentaries on the Roman-Dutch Law (Joseph Butterworth London 1820) 
Verbrugghe and Wickersham Berossos and Manetho

Verbrugghe GP and Wickersham JM Berossos and Manetho, introduced and translated: Native traditions in ancient Mesopotamia and Egypt (University of Michigan Press Ann Arbor 1996)

Vernus and Yoyotte The Pharaohs

Vernus $\mathrm{P}$ and Yoyotte $\mathrm{J}$ The book of the Pharaohs (Cornell University Press New York 2003)

Vincent 1904 Am J Sociology

Vincent GE "The laws of Hammurabi" 1904 (9) American Journal of Sociology 737-754

Wecht 2005 J Am Acad Psychiatry L

Wecht $\mathrm{CH}$ "The history of legal medicine" 2005 (33) Journal of the American Academy of Psychiatry Law 245-251

Weinberg $1951 \mathrm{Am} \mathrm{J}$ of Arch

Weinberg SS "Neolithic figurines and Aegean interrelations" 1951 (55) American Journal of Archaeology 121-133

Wells Outline of history

Wells HG The outline of history: Being a plain history of life and mankind (Macmillan New York 1920)

Winkelman 1990 Ethos

Winkelman MJ "Shamans and other 'magico-religious' healers: A cross-

cultural study of their origins, nature and social transformations" 1990 (18)

Ethos 308-352

\section{Register of legislation}

Constitution of the Republic of South Africa 1996

Constitutio Criminalis Carolina 1532 


\section{Register of internet sources}

Goodman 2008 www.thecanadianencyclopedia.com/

Goodman JT 2008 Mental Health The Canadian Encyclopedia

www.thecanadianencyclopedia.com/index.cfm?PgNm=TCE\&Params=A1A

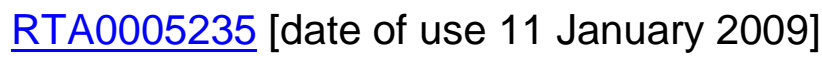

High et al 2007 www.egyptologyonline.com/

High T et al 2001-2007 Medicine and healthcare Egyptology Online:

Discovering ancient Egypt www.egyptologyonline.com/treatments.htm [date of use 11 August 2007]

Lyons 2007a www.healthguidance.org/

Lyons AS 2007 Ancient Egypt Health Guidance

www.healthguidance.org/entry/6310/1/Ancient-Egypt.html [date of use 09

August 2007)

Lyons 2007b www.healthguidance.org/

Lyons AS 2007 Ancient civilizations - Mesopotamia Health Guidance www.healthguidance.org/entry/6308/1/Ancient-Civilizations--

Mesopotamia.html [date of use 12 August 2007]

Pahor and Tadros 2006 www.ishm2006.hu/

Pahor AL and Tadros G 2006 Did the ancient Egyptians know about the psychopathology of suicide? Paper presented at the $40^{\text {th }}$ International Congress on the History of Medicine, Hungarian Academy of Sciences, Budapest/Hungary, 27 August 2006 www.ishm2006.hu/scientific/abstract. php?ID=247 [date of use 11 August 2007]

Refinetti 1992 www.circadian.org/

Refinetti R 1992 Philosophy of physiological psychology Circadian Rhythm Laboratory www.circadian.org/PPP/chap6.html [date of use 30 July 2007] 